\title{
Relaying the Foundations of Depression Economics for the Technology Age: Reintroduction of the Austrian School of Thought
}

\author{
Abhith Pallegar ${ }^{1}$ \\ ${ }^{1}$ Independent Researcher, India \\ Correspondence: Abhith Pallegar, Independent Researcher, India.
}

Received: August 1, 2017 Accepted: August 16,2017 Online Published: August 31,2017

doi:10.5539/ibr.v10n10p10 URL: https://doi.org/10.5539/ibr.v10n10p10

\begin{abstract}
Structural changes in the modern economy have diminished the impact of traditional monetary and fiscal policies. For the past 90 years, the field of depression economics has been dominated by the Keynesian school of thought, which advocated the judicious use of monetary and fiscal policies by governments to artificially create aggregate demand to bring the economy roaring back from a recession. Today, economies are more diversified entities and large sections of these economies cannot be stimulated by monetary and fiscal policies. This paper discusses future of fiscal and monetary policy in an age of rapid technological change. The current scenario calls for the reintroduction of the Austrian School to the mainstream thought process for effectively managing future business cycles.
\end{abstract}

Keywords: Austrian economics, depression, economics, technology, monetary policy, fiscal policy, structural change, financial crisis

\section{Introduction}

Keynesian economics, which was the driving force for understanding depression economics since the 1930s, advocated the loosening of monetary policy by central banks and fiscal policy by governments to weather economic storms. (Blinder, A. S., n.d). According to Keynesian principles, an economic depression, which is defined as the absence of aggregate demand in the economy, can be corrected by government actions. (Jahan, S., Mahmud, A. S., \& Papageorgiou, C., 2014). The slowdown or depression in an economy is due to the output gap which can be plugged to bring the economy back to its heydays. Earlier, proponents of Keynesian policies relied on making capital investments as they were looking for a spurt in construction and manufacturing sectors to boost the economy from a depression. America emerged from the Great Depression of 1929 only after the war effort and later with the establishment of the interstate highway system and other large capital projects fueled the recovery of the economy.

If we look at the breakdown of GDP of advanced economies such as the US and the UK as illustrated in this paper, we see that the share from the manufacturing sector in their GDPs has fallen since the 1970s. We see a steady decline in the manufacturing and production industries as a percentage of their contribution to the overall economic output. This is in some part because of the emergence of other sectors which have begun taking a greater share of the economic output. The fact that the manufacturing sector was steadily moving to and being embraced by developing countries is another factor that contributed to this decline. Nowadays, it is almost impossible to come across developed economies where $40 \%$ of GDP contribution comes from manufacturing like it did in the past and employment levels in these sectors have plummeted from their historic highs. The graph of GDP breakdown of main developed economies of the US, the UK and Japan show dominant structural changes witnessed since the 1970s. The manufacturing sector contribution to the economic GDP is having a diminished influence; it is these same sectors that the Keynesian economics tries to influence.

Long-term GDP is dependent on productivity which is enabled by technology. Short-term growth has historically been mainly influenced by governments through their monetary policy. Most governments usually go for shortterm stimulation of the economy using monetary policy or fiscal policy to respond to a financial crisis. Using fiscal and monetary policies to stimulate the economy in the short term will not have the same influence it once had since modern economies are structurally reoriented away from manufacturing and construction sectors. A 
large part of economic growth comes from consumer spending which does not change drastically in the short term. In addition, economic output coming from capital spending will have lesser influence in the economy going forward. Since a greater ratio of GDP addition comes from developing technology and related services, the amount of incremental GDP coming from the construction of roads or bridges is limited. Technology as a GDP component cannot be meaningfully influenced in the short and medium term with monetary and fiscal policy.

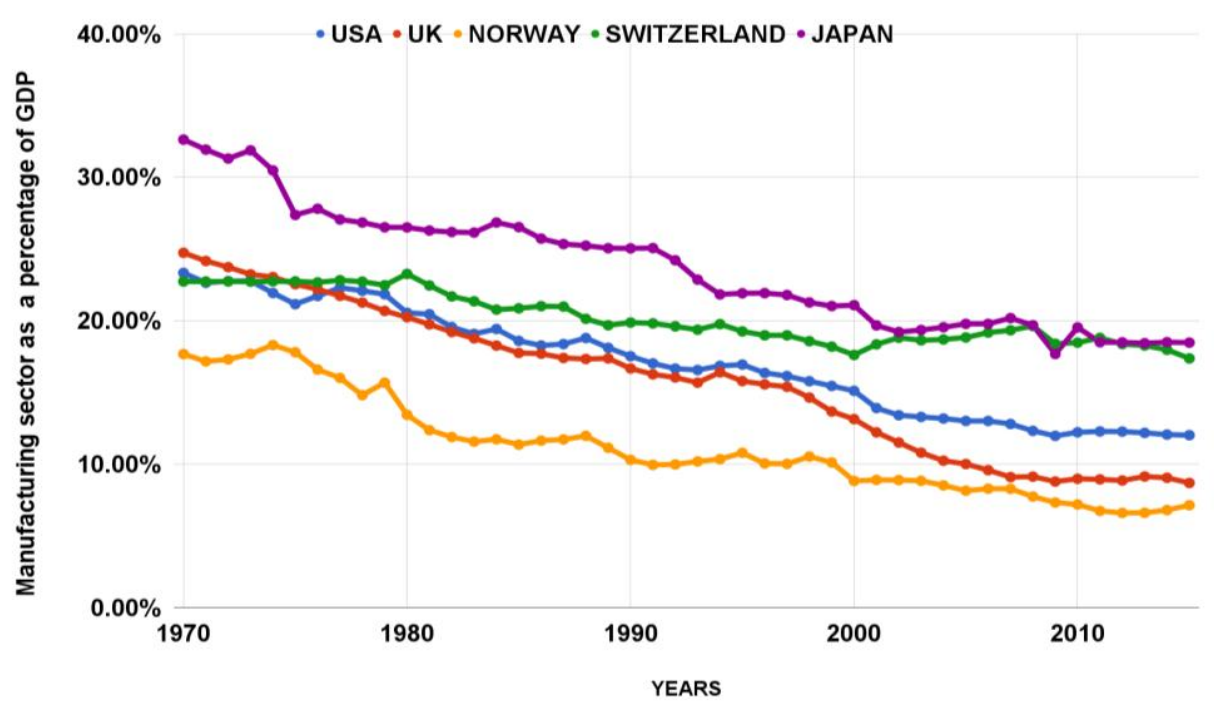

Figure 1. Manufacturing as a Percentage of GDP of Selected Developed Economies in Current Prices in National Currency

Source: (National Accounts Main Aggregate Database, n.d)

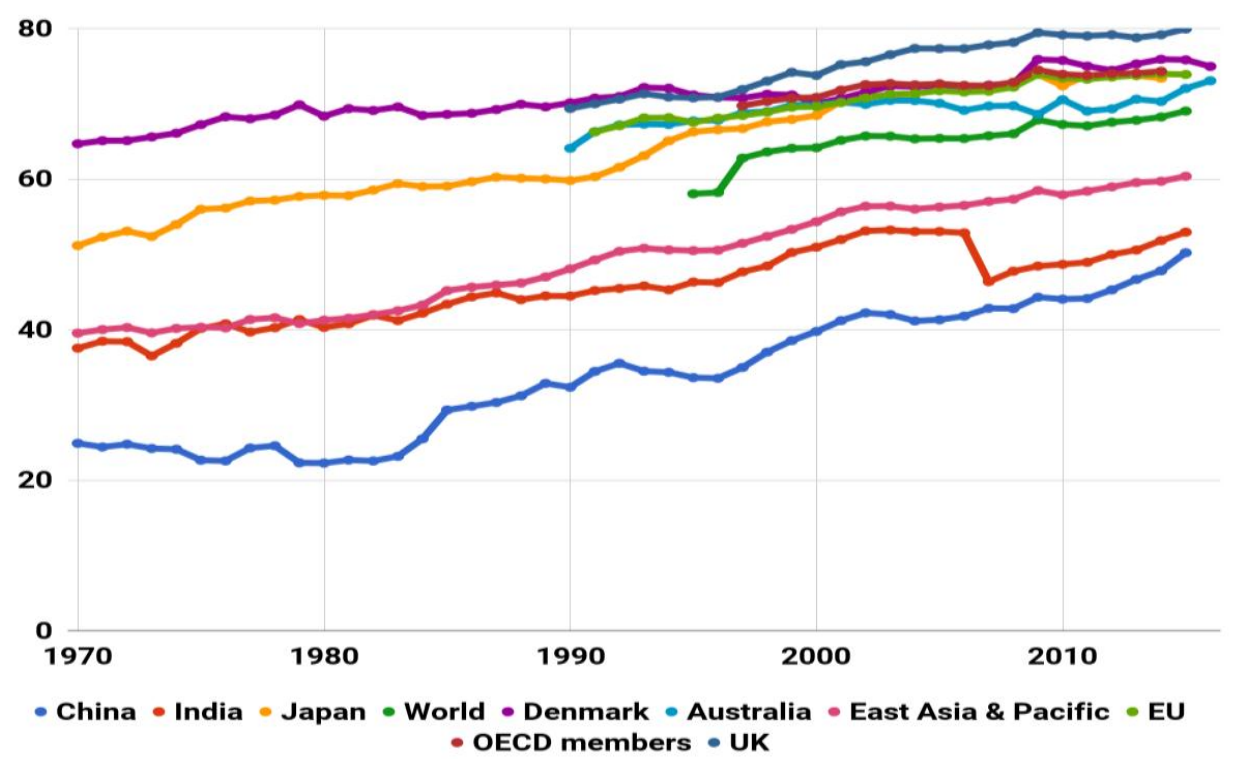

Figure 2. Services as a Percentage of GDP of Selected Developed Economies in Current Prices in National Currency

Source: (World Bank Group, n.d)

Ever since its emergence in the 1960s, the Information Technology (IT) sector has been claiming a significant share in the GDP of many countries and the driving force behind much of their economic gains. There has been an exponential increase in the productivity gains in the economy, which can be attributed to two things - humans were embracing the computing power more readily than ever and human capacities were being augmented with the aid of computers. 


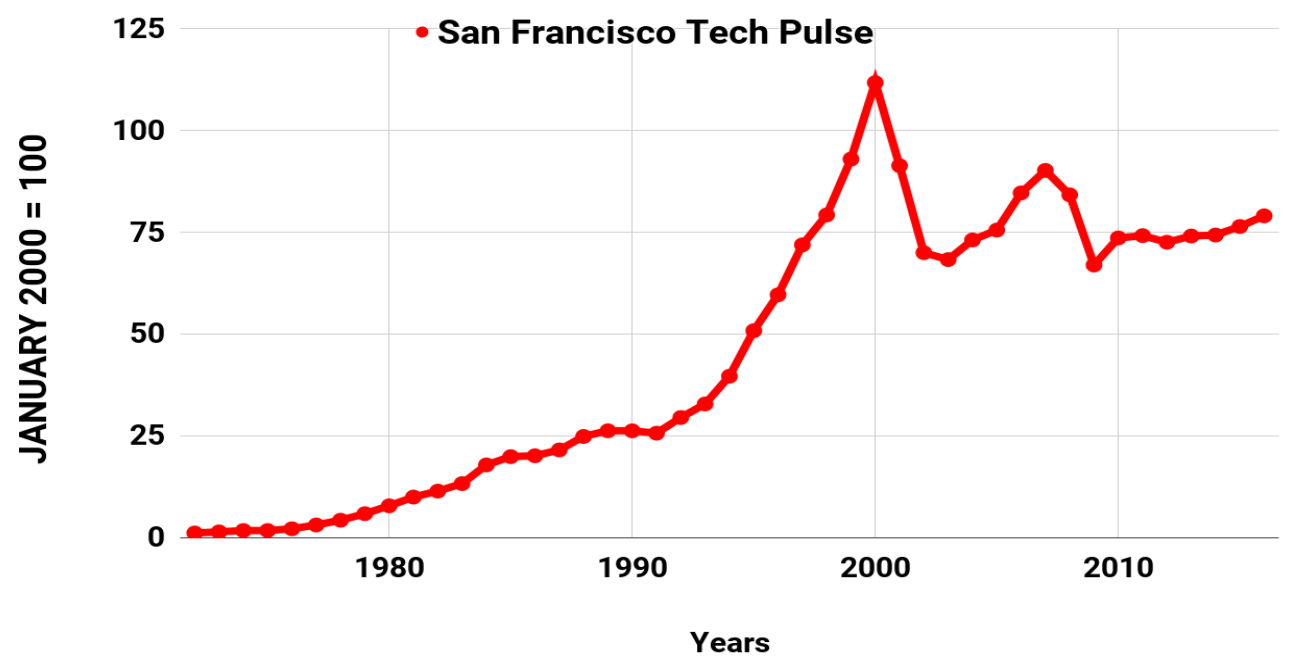

Figure 3. San Francisco Tech Pulse

Source: (Federal Reserve Bank of St. Louis, 2017)

Figure 3 is a coincident indicator of the vigor of the US Information Technology sector. The spectacular rise in the IT sector, as seen in the figure, corresponds to the steady decline in the importance of manufacturing sector on the economy. Employment levels have dropped significantly in the last few decades. With the dis ruptive impact the invention of the microprocessor had on the economy, we saw the sands of economic GDP shifting and the economic influence of manufacturing, mining, and automotive sectors diminishing.

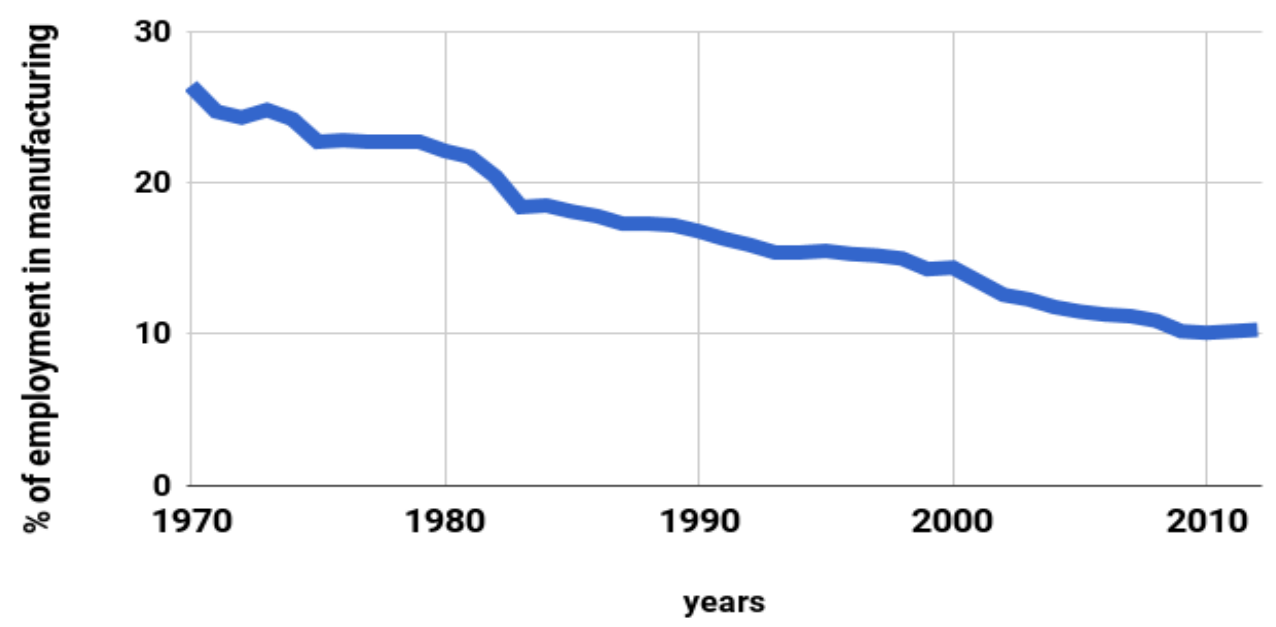

Figure 4. Percent of Employment in Manufacturing in the United States annual (Not Seasonally Adjusted)

Source: Federal Reserve Bank of St. Louis (2012)

The existing literature on depression economics needs to be rewritten to include the structural reorientation of the economy away from capital-intensive industries and how this impacts the use of monetary and fiscal policies in the economic management of nations. Vast libraries of knowledge need to be reworked to factor in the structural changes the economy undergoes and how policy tools need to be rethought for effective economic management.

But going forward, the direct relationship fiscal and monetary policy had on economic growth will have a diminished effect. The Long-term structural changes in the economy will make it unresponsive to government actions. Modern economies are much more diversified than they were a century ago and therefore, stimulating them during a crisis is not as easy and straightforward as it had been in the past. Today, developed economies are less able to have a traditional V-shaped recovery like they did historically for the past 80 years since capital spending is only a small component of the GDP and immediate recovery cannot be expected through government actions. 


\section{Government Action}

After the 2008 crisis, we have seen governments using fiscal policies and more so monetary policies to get their economies back on a growth path. Such attempts, however, had only a marginal impact because the money has not gone to fuel industrial growth like they hoped it would, but straight into the stock market. The major central banks such as the Federal Reserve of the United States of America, the Bank of England (BoE), and the Bank of Japan (BoJ) have engaged in major quantitative easing policies believing that the economy will come roaring back. However, a cursory analysis of the matter shows that notwithstanding these attempts, their economies didn't recover in the magnitude or to the extent they were expecting it would.

In response to the financial crisis, central banks around the world have lowered interest rates to prop up the economy by providing it the additional aggregate demand it was in need of. These rates have been falling around the world and the drop in interest rates is glaringly obvious since 2008. The drop in the short-term rates of central banks has forced the long-term yields to historical lows.

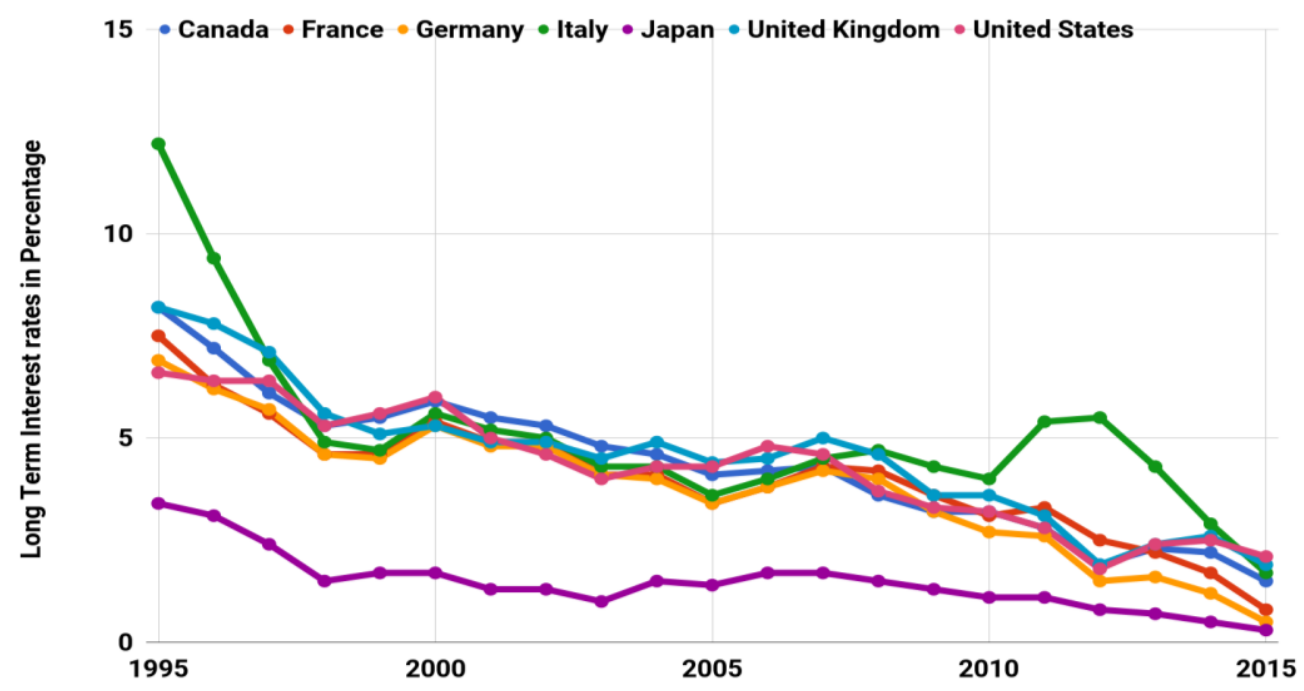

Figure 5. Long-term Interest Rates of Selected Major Economies, 1995-2015

Source: (Organization of Economic Co-operation and Development, 2017)

Even though the financial crisis originated in the US and initially spread to europe we see some of the developing countries also had to lower interest rates to stimulate demand in their respective economies to counter the reduced demand from the developed countries for goods and services.

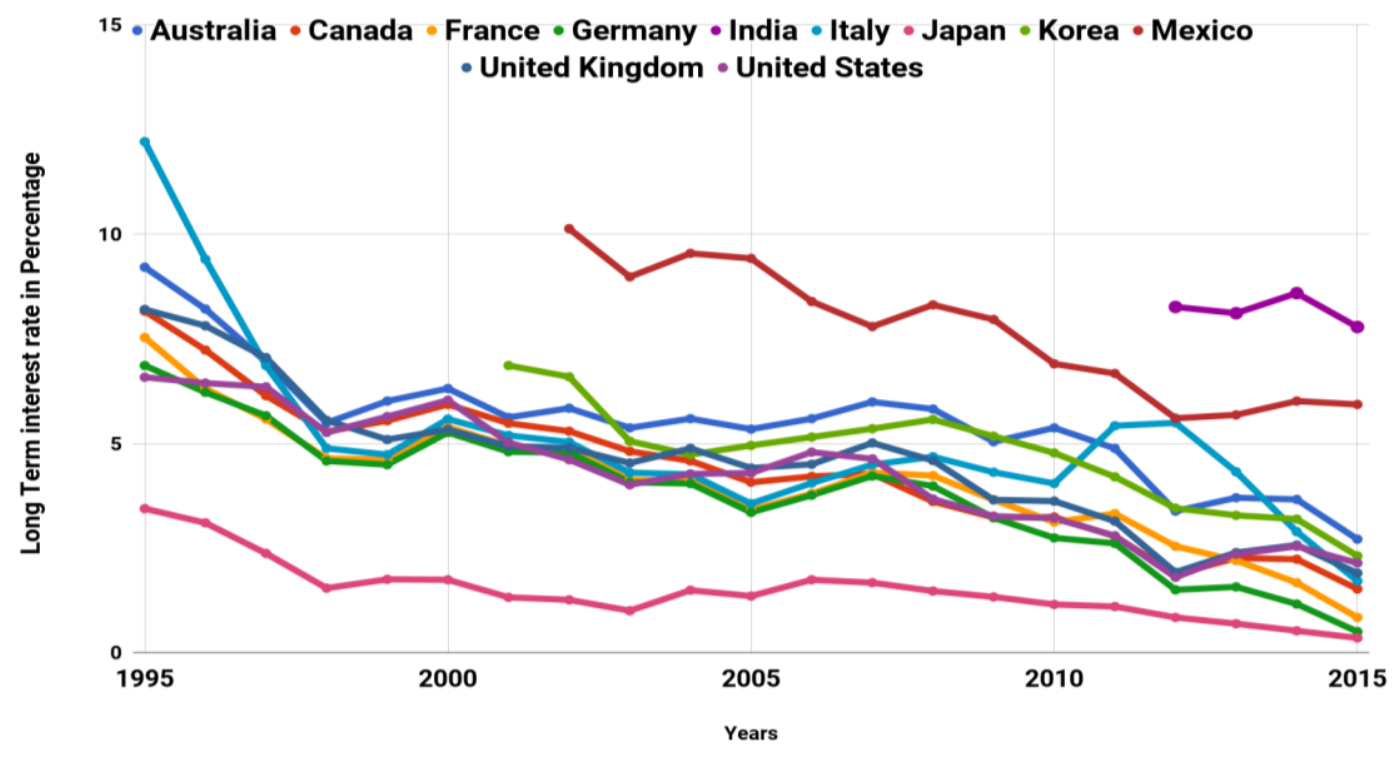

Figure 6. Decline in Long-term Interest Rates of Selected G20 Economies, 1995-2015 
Source: (Organization of Economic Co-operation and Development, 2017)

This expansionist approach to money supply has not only reduced interest rates in the short term and long term but also greatly expanded the assets central banks carry on their balance sheet. The graphs given below show the scope of central bank activities of the ECB in the Euro area and the Federal Reserve in the US. The ECB has expanded its asset base through the use of quantitative easing from less than a trillion Euros in 2000 to over 3.5 trillion by 2016, a steep increase after the catastrophic events in the financial markets in the year 2008. The Federal Reserve has been involved in the financial markets more than the ECB by quadrupling money supply in a decade.

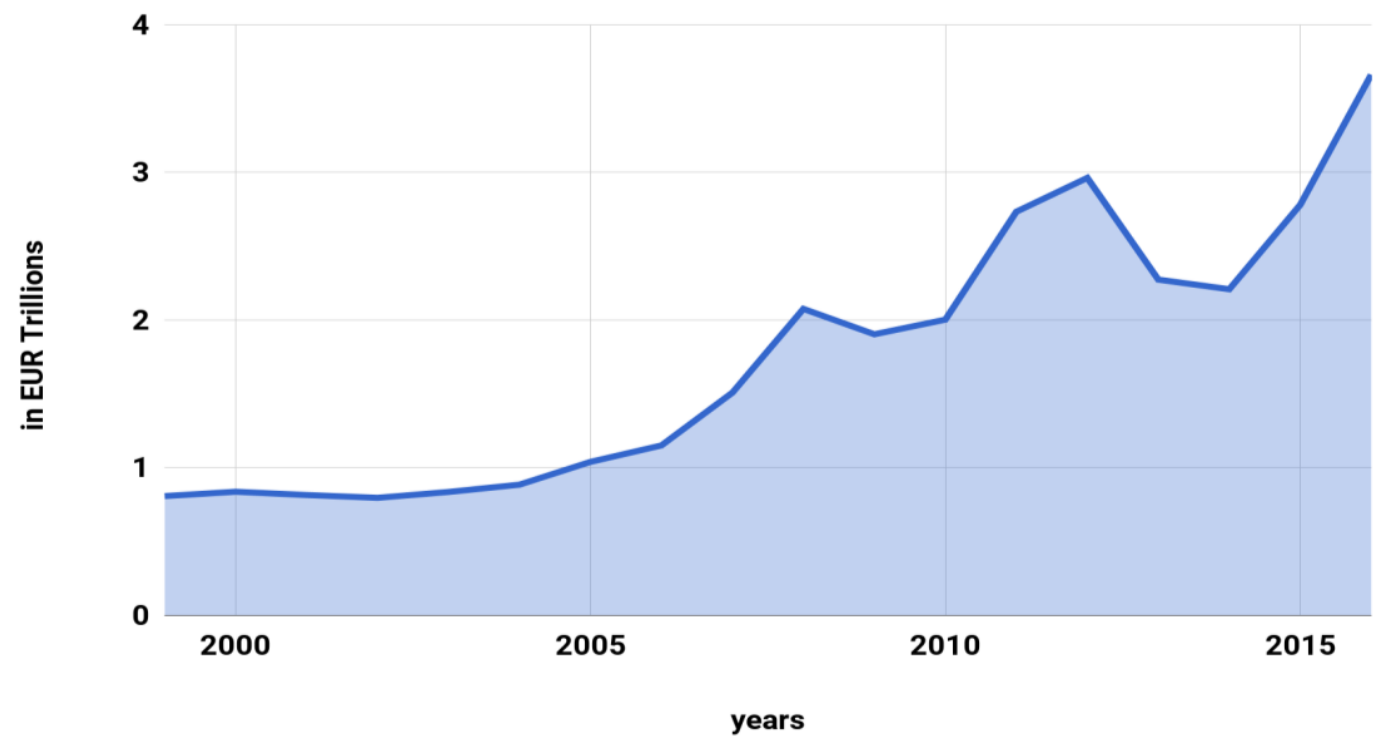

Figure 7. Historically Significant Expansion of the ECB Assets on Their Balance Sheet Since 2008 Source: (Annual Consolidated Balance Sheet of the Eurosystem, n.d)

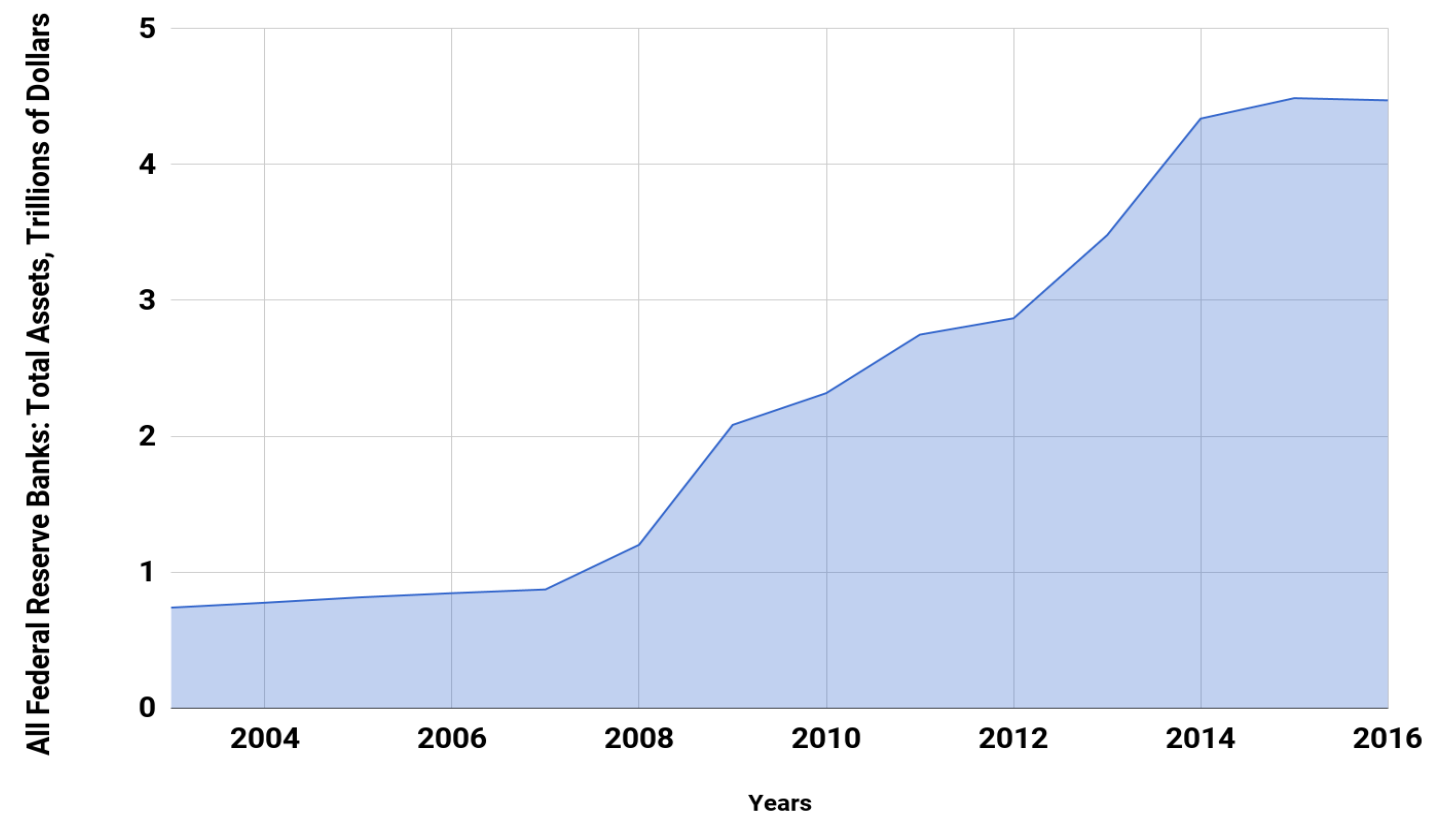

Figure 8. All Federal Reserve Banks: Total Assets, Millions of Dollars, Annual, Not Seasonally Adjusted Source: (Federal Reserve Bank of St. Louis, 2017) 
Figure 9 shows the expansion of Federal Reserve's balance sheet assets to an all-time high of $25 \%$ of GDP.

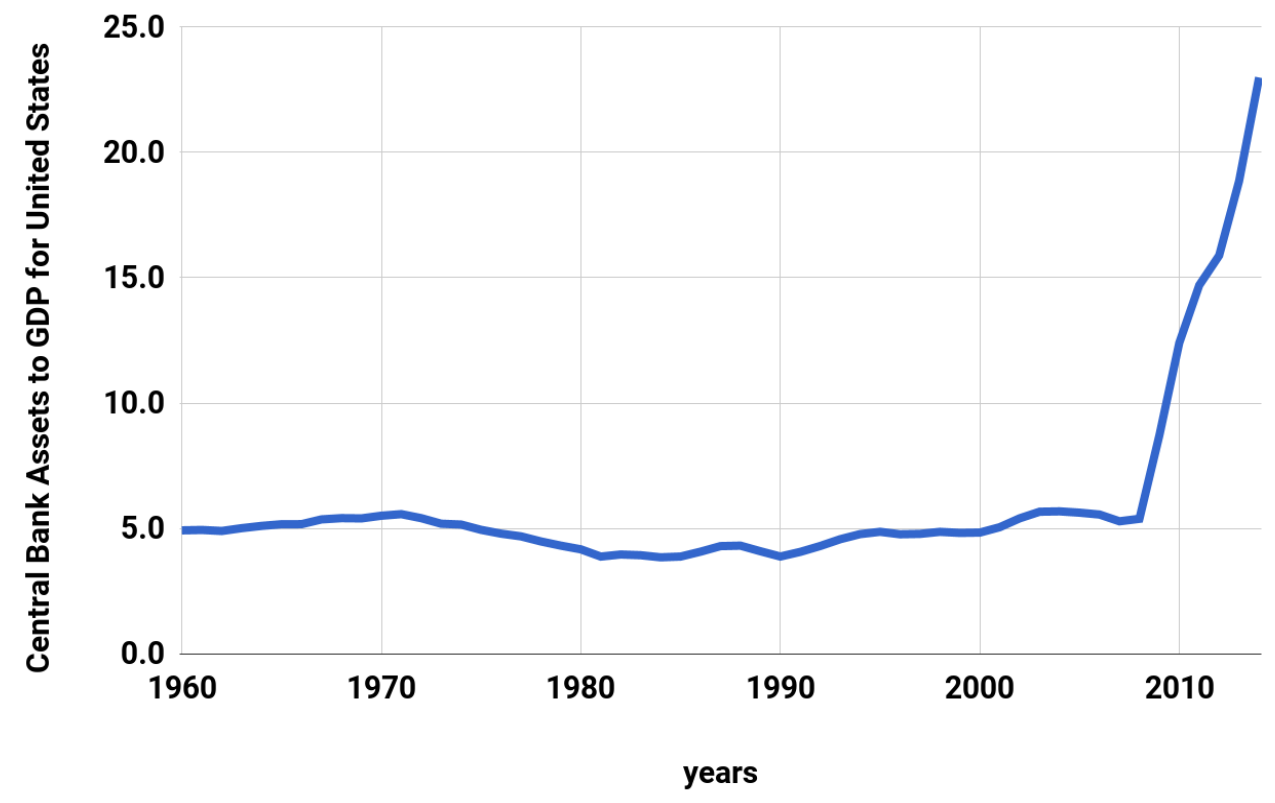

Figure 9. Historical Central Bank Assets to GDP for the United States

Source: (Federal Reserve Bank of St. Louis, 2017)

Government spending has also spiked in G7 economies to prop up the economy in addition to the lowering interest rates as a part of their expansionary fiscal efforts. However this is less compared to what's done on the monetary front.

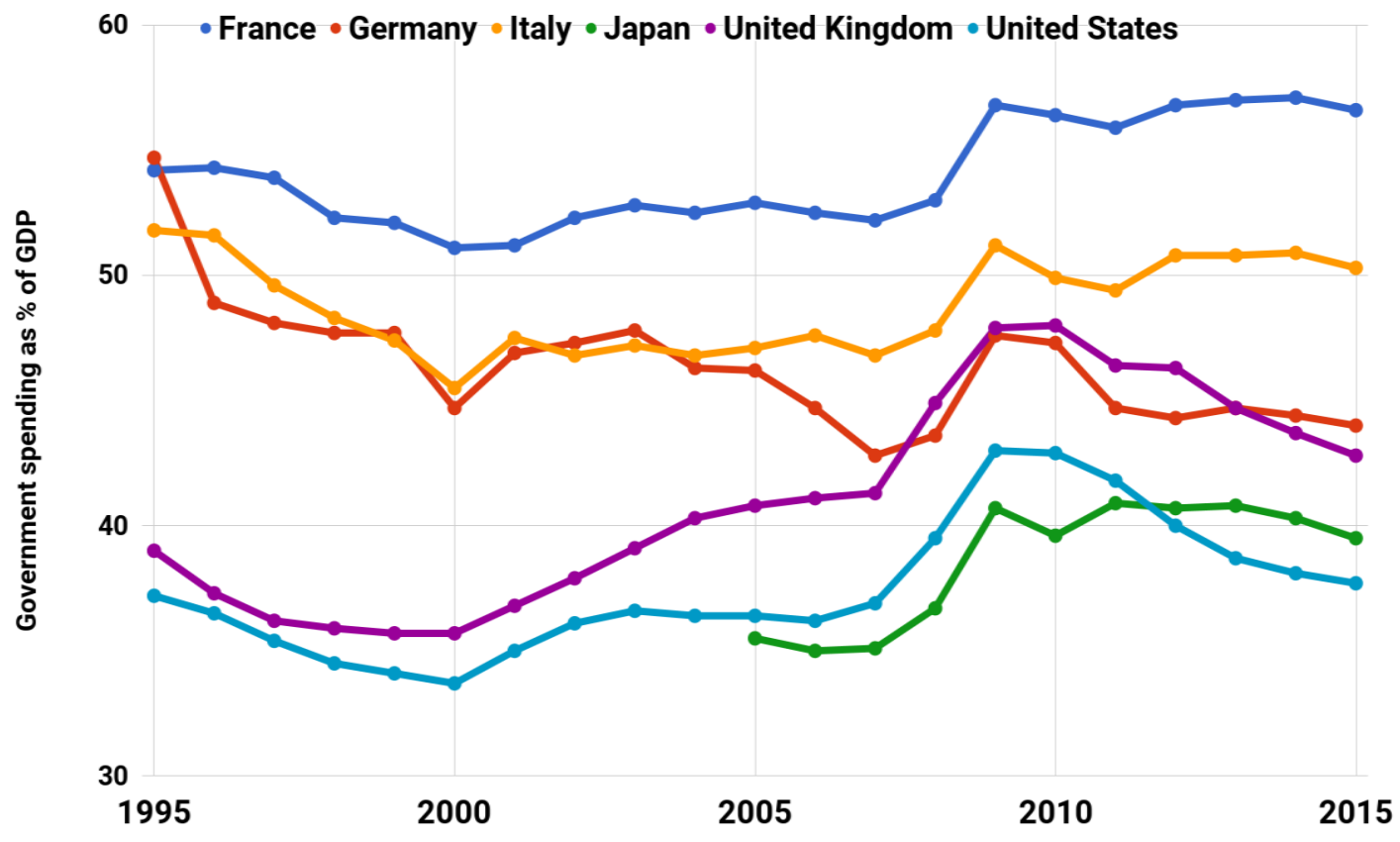

Figure 10. General Government Spending as a Percentage of GDP of G7 Economies

Source: (Organization of Economic Co-operation and Development, 2017)

Since the bursting of the housing bubble in 2008 , governments have pumped vast quantities of money into the economy to stimulate economic activities. The Federal Reserve assets have expanded to approximately 4.5 trillion dollars as of 2016. Although the Keynesian approach might have been successful in averting an economic disaster through monetary policy, it didn't have the same success in leading the economy to a path of sustained 
growth. About $\$ 12.3$ trillion was spent by central banks in quantitative easing programs between 2008 and 2016 , but these attempts have not yielded extraordinary rates of growth to reap back economic output lost during the crisis. (Cox, J., 2016).

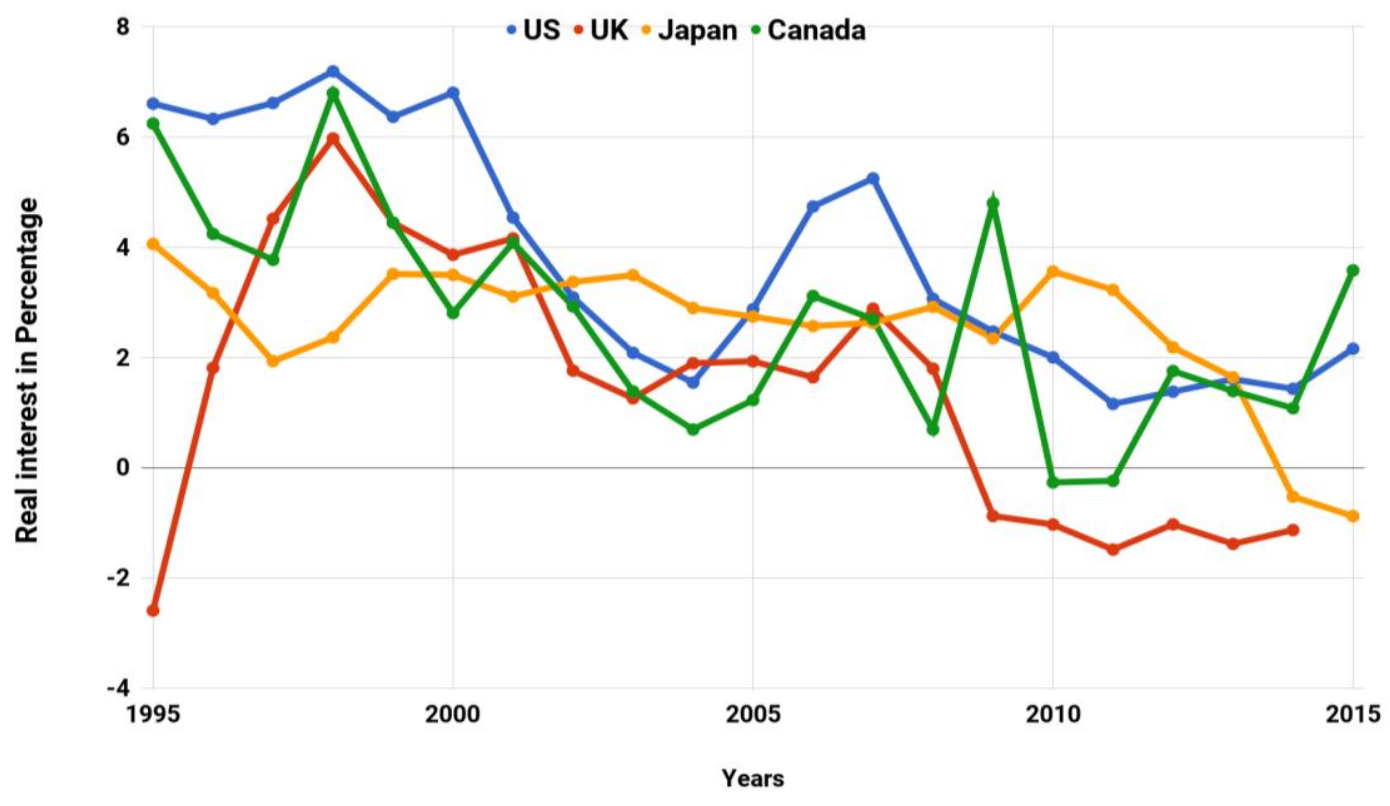

Figure 11. Real Interest Rates of Selected Developed Economies

Source: (World Bank, n.d)

With the efforts of their central banks, the real rates of many European economies along with the UK and Japan are in the negative territory. There is not much room for quantitative easing without going negative i.e. by paying the borrower to borrow money. The policy mechanism that has worked so far has stopped working like a patient who has developed resistance to the medicine. The policy mechanism that was used as a standard policy prescription in the economic practice for almost a century has run out its usefulness in this newer and more complicated era.

Lending rate is the rate at which the private sector can obtain short or medium term financing based on creditworthiness. The figure below shows a significant drop at which private institutions can borrow in selected economies. Lending interest rates of many economies have fallen since the 2008 crisis as a result of deliberate government policy response.

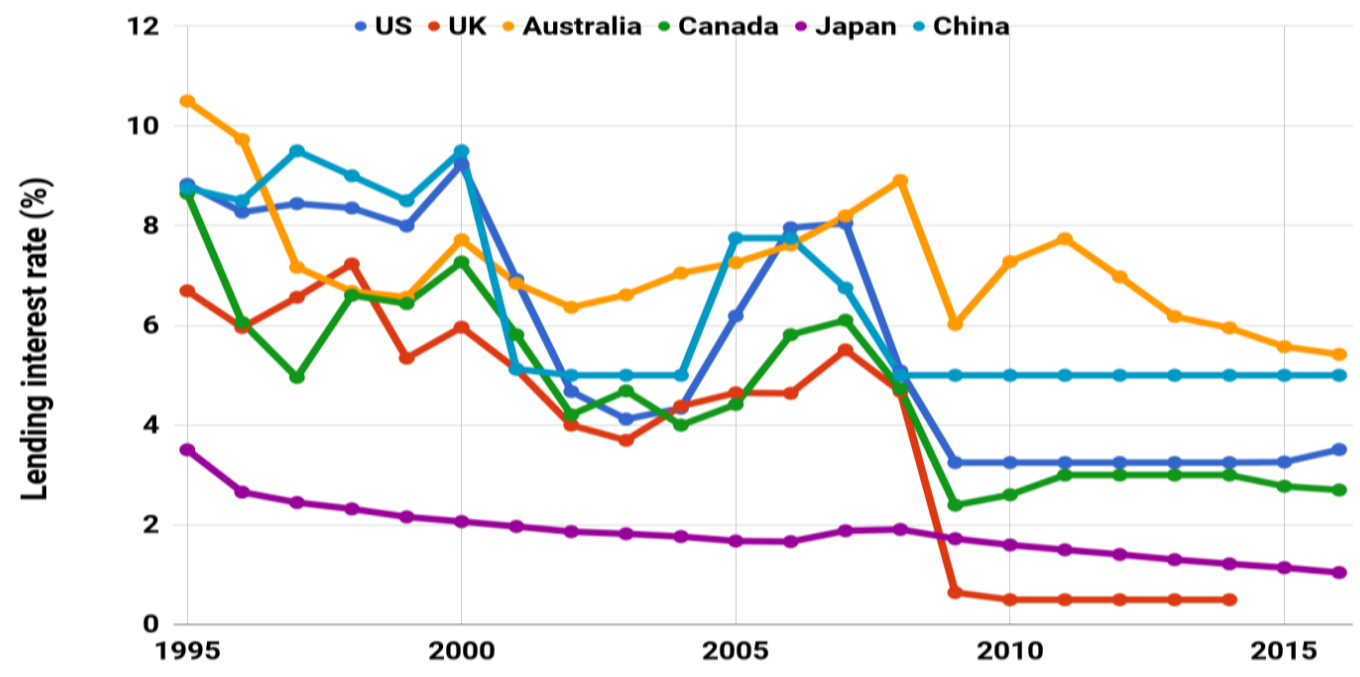

Figure 12. Lending Interest Rates in Selected Economies

Source: (Organization of Economic Co-operation and Development, 2017) 
Such a drastic reduction in borrowing rates for the private sector may lead to significant inefficiencies in the financial system. Risk in the economy is similar to a company that has borrowed heavily during the boom years and facing increased risk of bankruptcy during difficult economic times. The risk accumulated in the financial system may cause long-term negative consequences for the economy. Since leverage significantly increases the gains during good years and losses during bad years, the accumulation of debt in the system leads to the exponential accumulation of risks within the system which will eventually lead to severe financial crashes.

\section{Economic Growth?}

Low interest rates provide cheap long-term financing for institutions to invest in the economy but expected levels of growth are not observed in the real economy. In this new era, lower rates do not necessarily mean increased growth in the economy. Much of the gains the US economy made during the boom years after 2000 were lost in the 2008 crises and their economy has not made any substantial gains to recover the lost economic output. The world has not gone back to the growth rates seen during the boom years - i.e. the years before the 2008 crisis.

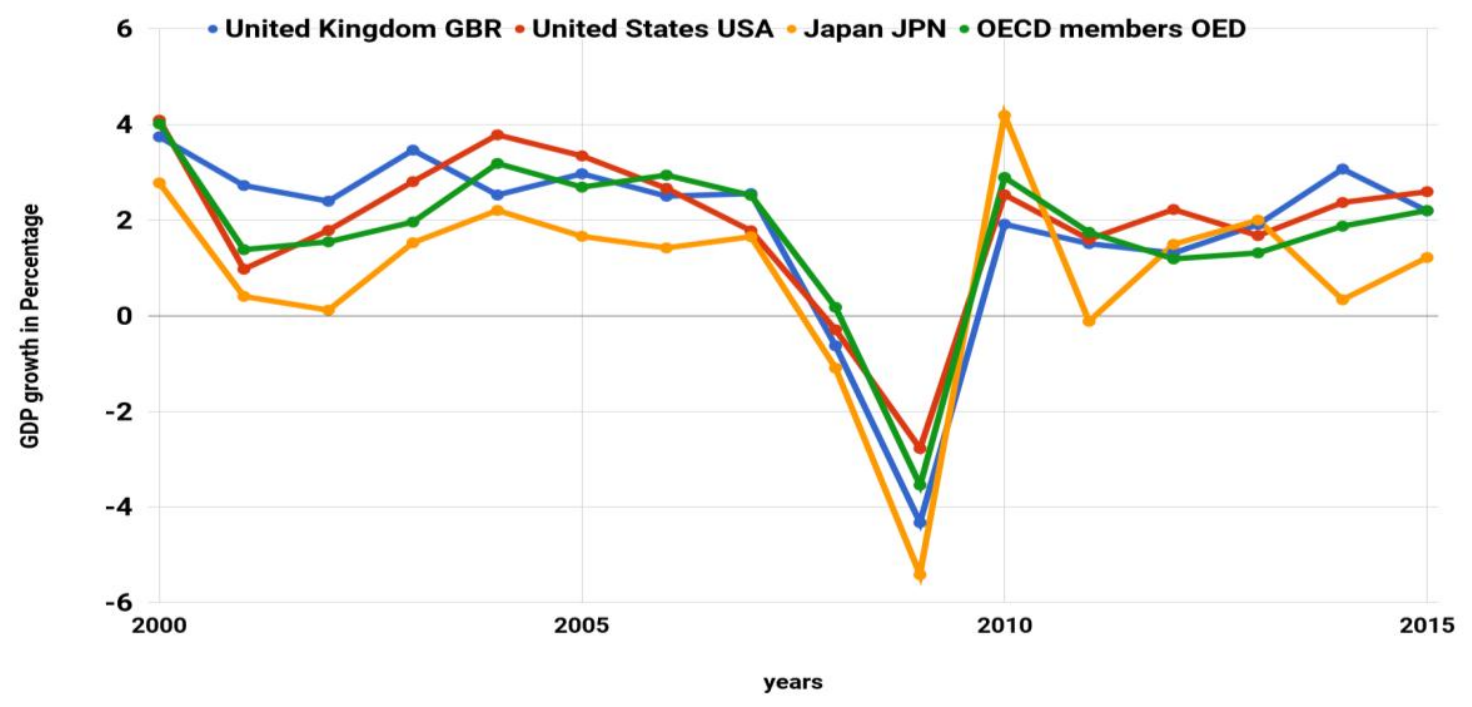

Source: (World Bank, n.d)

Figure 13. Annual Percentage Growth Rate of GDP

All these measures taken by countries have not contributed to any significant growth in their respective economies. The old idea that we can dramatically improve the economy by central bank interventions is waning. The structural change these economies have witnessed has not been filtered into the policy prescription that is currently in use. We have entered an era where old policy tools are no longer effective to achieve macroeconomic goals. Central banks were once able to influence short and medium term interest rates to produce growth. Interest rates don't directly influence the economy the way level of technological advancement and R\&D budgets does today. Even though interest rates are low, it does not mean investments are profitable enough to spend sufficiently on R\&D. Going forward the study of macroeconomics should acknowledge its close relationship with fast-moving technology.

\section{Blowback from Government Actions - Increased Debt in the System}

The government policy of lowering interest rates has led to increased debt levels in many countries. Government debt as a percent of GDP has spiked dramatically since the 2008 financial crises and countries are borrowing heavily to prop up their economy. As a corollary, debt levels have been at the historical highs not seen since the World War II.

As it becomes evident from all the government actions after the 2008 crisis, debt in the system is a grave problem. Not only the government debt but also the household debt is rising to historical levels. Risks accumulate as debt in the system rises. Institutions in the financial system are heavily leveraged, making the system more susceptible to crises. This is systemic risk threatening the financial system. This shows us that keynesian policies are vastly increasing systemic risk and not contributing to a healthy economic recovery. 


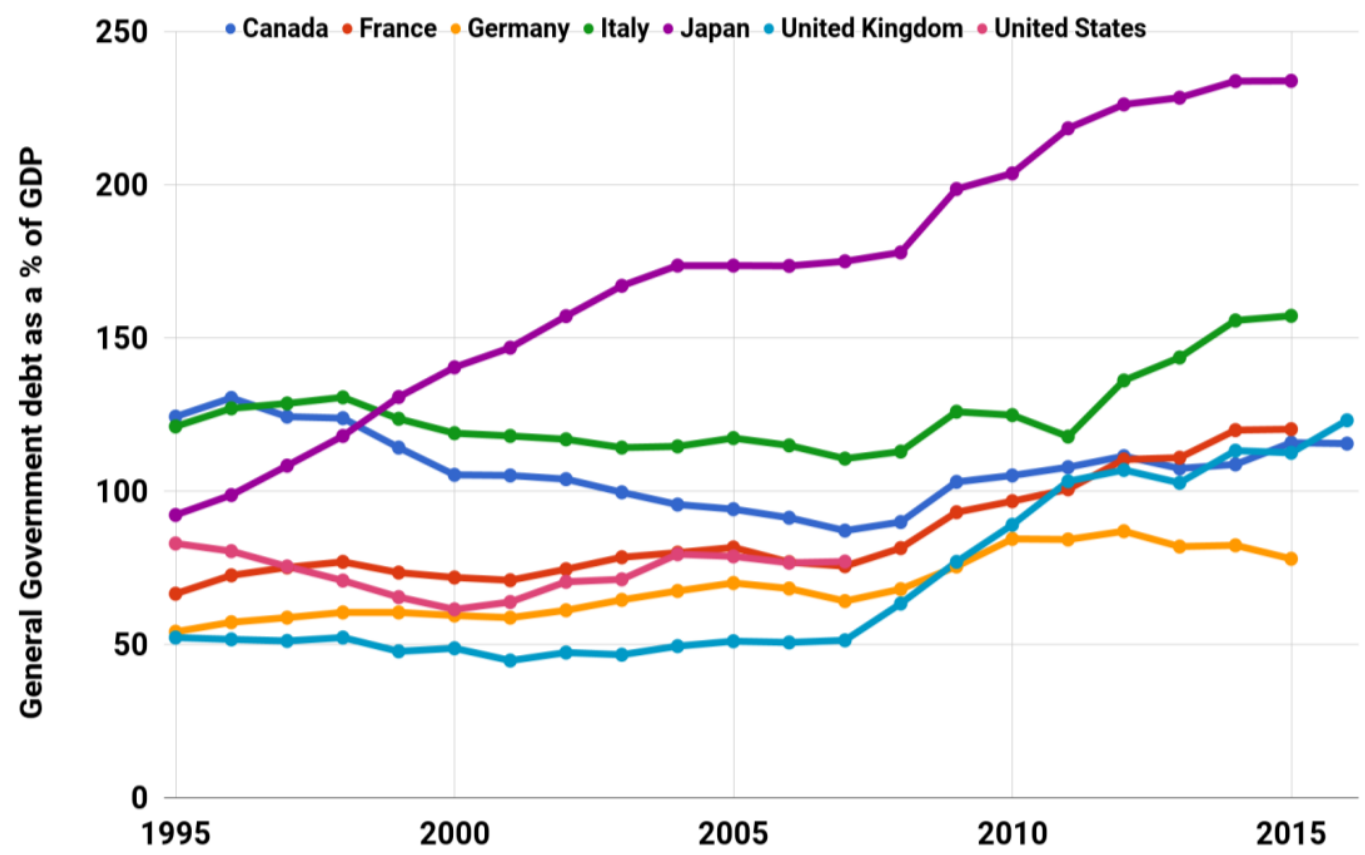

Figure 14. Government Debt as a Percentage of GDP of G7 Countries

Source: (OECD, 2017)

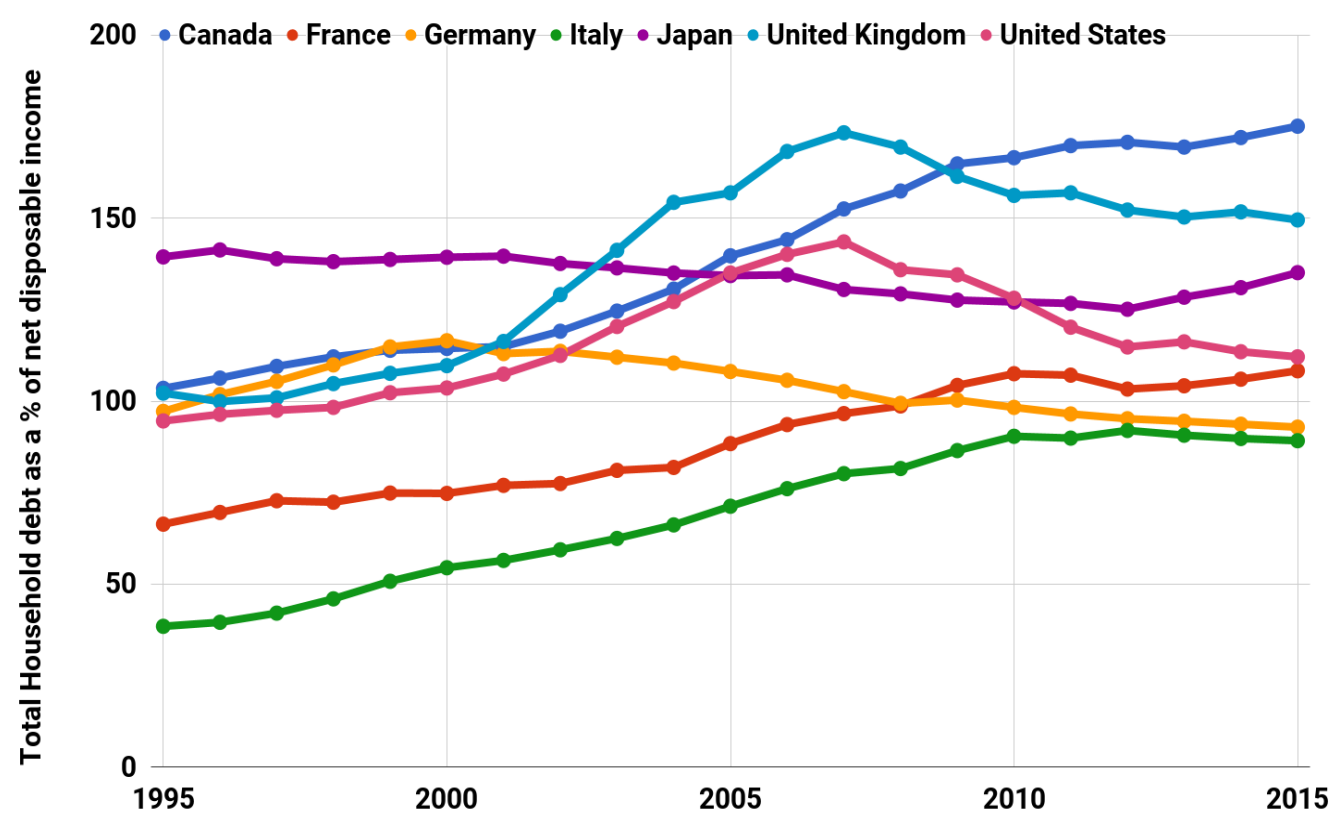

Figure 15. Total Household Debt as a Percentage of Net Disposable Income, 1995 - 2015 of G7 Economies Source: (OECD, 2017)

The Keynesian economics deals with plugging the shortfall in the aggregate demand by influencing the key industries in a given economy. In most advanced economies, manufacturing and construction of roads and bridges do not occupy the lion's share of economic activity to drive growth like they did during the times of John Maynard Keynes. They, on the other hand, pi vot around IT services and consumer consumption. Consumer consumption has historically been very stable and it is rather difficult to influence it. The share of manufacturing as a percentage of GDP has been undergoing a long-term decline in the world and the weight of innovation to drive growth is a trend on the rise. (Perry, M. J. 2012). Policy tools developed in the past no longer have the same magnitude of impact they once had. Since modern economies can be less directly influenced by deliberate government policy, there is a need for a new strategic direction in thinking about depression economics. 
Breathing new life into an old depression economics theory that has been forgotten in the modern times is the Austrian School of thought.

\section{Reigniting the Austrian School of Thought}

We need a new business cycle theory for the new age of fast technological progress. For this, the paper turns its focus to the Austrian School of Thought. Austrian Economics, which advocates for a laissez-faire approach to managing markets may be more suitable for economies where the short-term impact of monetary and fiscal policies has diminished relevance. Laissez-faire meaning a vastly reduced role of the government in the free market and restrained reactionary policies to the market movements. Light touch regulation is the only plausible solution in the fast moving technology driven marketplace. Austrian economists view recessions as necessary readjustments in the economy through which the wasteful spending built up in the economy during the boom years is removed. (Rothbard, M. N., 1978). This school of thought advocates for no policy change so that the economy can readjust to new economic conditions. It dismisses the use of monetary and fiscal policies to prop up the economy during bad economic times; instead, it pushes for a natural process of reorganization in the economy.

Many European economies are increasingly relying on tourism (World Travel and Tourism Council, 2015), which cannot be influenced in the short term with government policies, and less on manufacturing for their economic growth. Since modern economies are less responsive to government actions in the short term, the Austrian School gives us necessary guidelines when dealing with an economic slowdown. A new foundation for the Austrian economics needs to be built, not on the principle of laissez-faire economics but by viewing laissezfaire economics as a consequence of fast-paced technological change. Understanding the economy in the way Austrian model suggests would be more relevant when technology cannot be changed in the short term. Governments are capable of making headways in technology in today's age not by using central bank policies but by investing in science and technology. Take, for instance, the case of the American space program from which the world benefited enormously. It was the extraordinary vision and the leadership in technological advances, not the intelligent monetary policies of central banks that made this program possible.

\section{Introducing Technological Cal culus into Policy Making}

Technology has been an area of significant advancement for human societies. Technology has its influence on every sphere of human life including humanities, anthropology, sociology and demography. The breathtaking pace of innovation will change the way we view politics and economics and their coming together in the functioning of the political economy. While developed countries have become more dominated by service sectors, China has become world's factory for producing manufactured goods. The boom in IT and ITes services has fundamentally restructured economies away from traditional industries and into economies that are predominantly driven by innovation and technology. Much of the growth in the 1990s for the US came from the introduction of computers to the workplace. The R\&D budgets are a driver of GDP growth today more than manufacturing, construction or mining sectors; these sectors are no longer form the core of the economy. These condition makes a form of laissez-faire economics like Austrian model more suitable to a modern composite economy than traditional keynesian interpretation. 
Figure 16 shows the total patent applications filed under the PCT (Patent Cooperation Treaty). It is indicative of the exponential pace of innovation the world is witnessing just in the last 15 years. As the numbers would show, a major portion of recent innovation gains comes from developing countries like China.

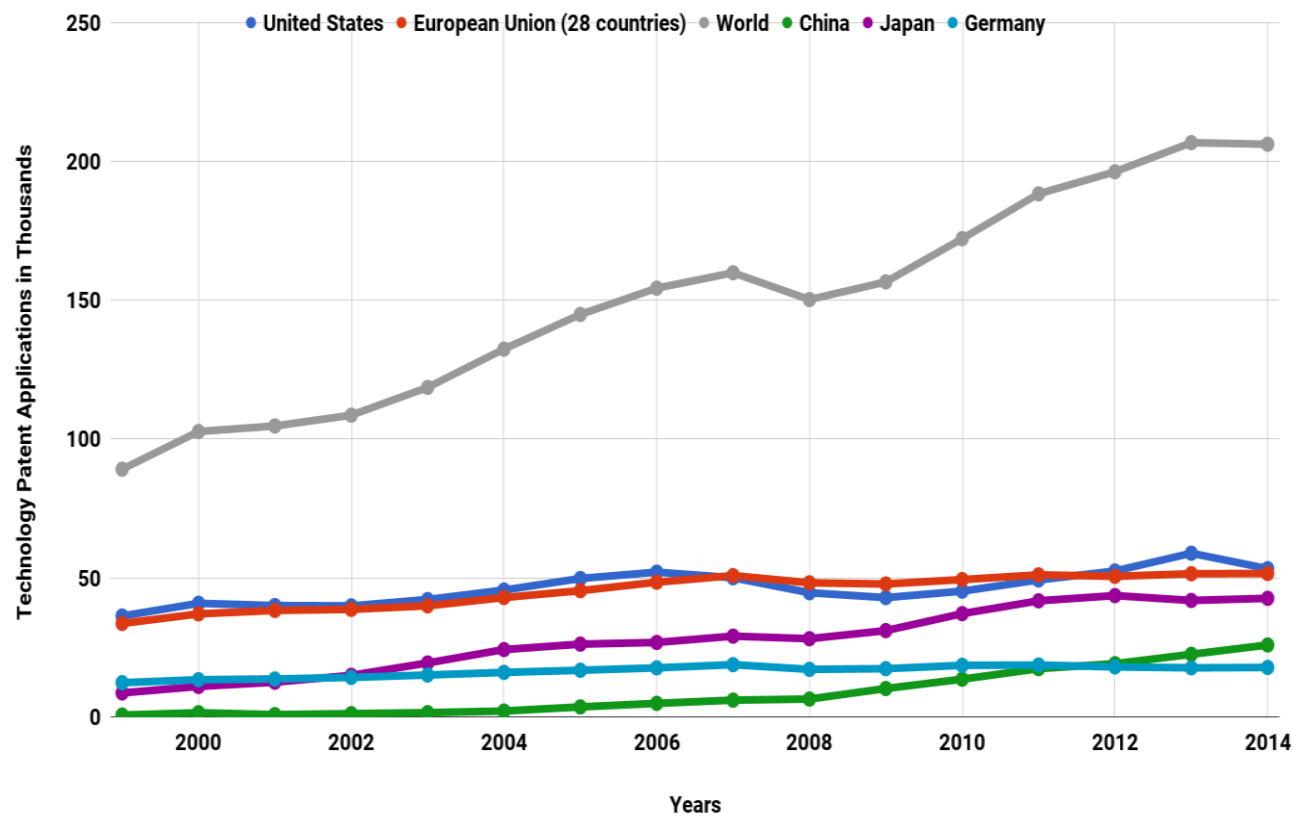

Figure 16. Technology Patent Applications filed with PCT since 2000, in Thousands

Source: (Patents by Technology, n.d)

The perspective on policy will have to be radically changed in order to accommodate factors that were in some ways less emphasized previously in economics. Technology has always been there in the background of economic narrative, but a discourse on the pace of technological change was never more at the forefront since the inception of the field of economics. Figure 17 shows the rising trend of spending on R\&D as a percent of GDP. The understanding that technology is important to bring forth growth for developed economies has come to the forefront and been translated into actual policies.

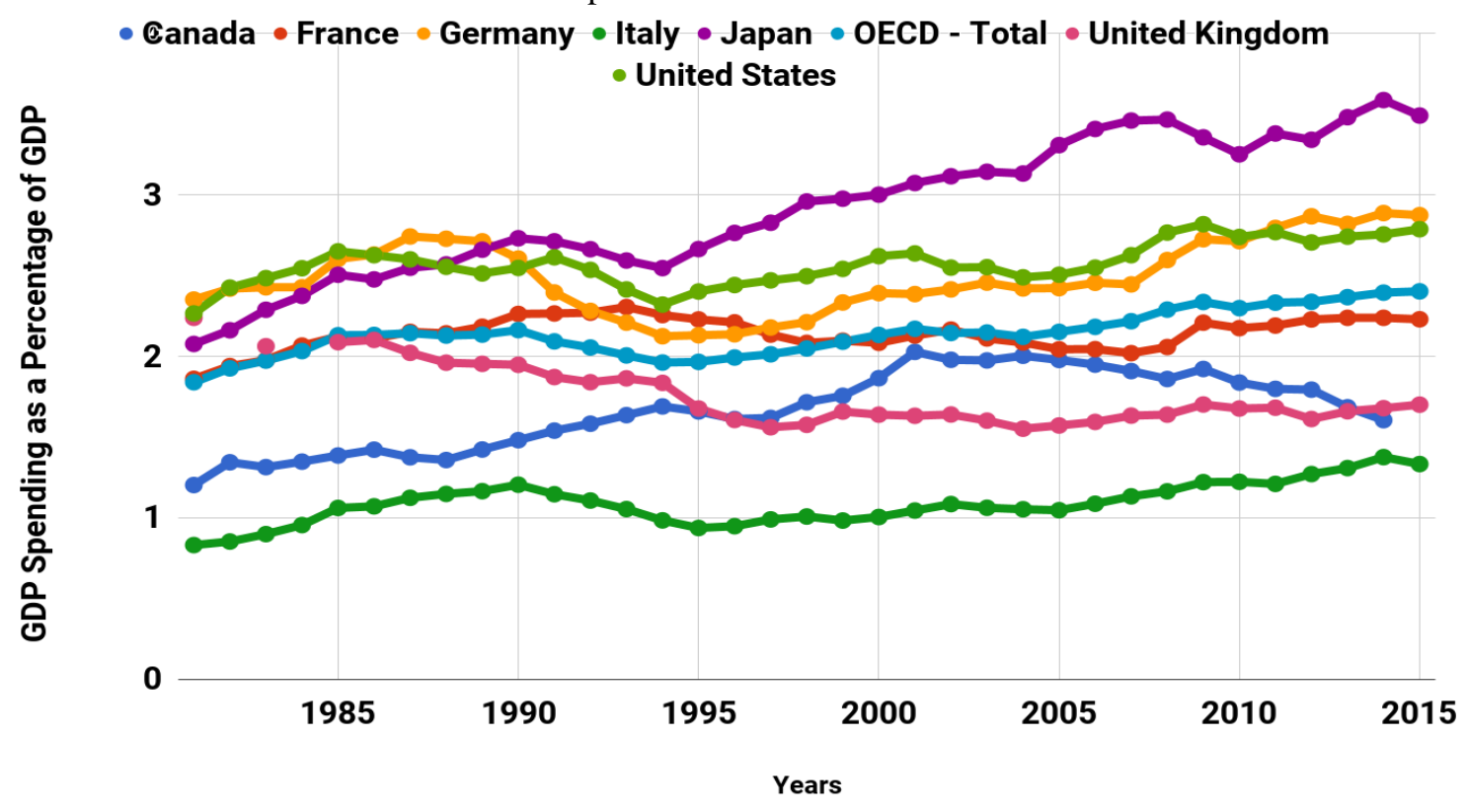

Figure 17. Gross Domestic Spending on R\&D Total as a Percentage of GDP 1981-2015 of selected G7 Economies and OECD, excluding China

Source: (OECD, 2017) 
The following figure (Figure 18) shows the employment figures of number of researchers per thousand employed of selected countries. This can be viewed as a proxy for greater emphasis on research in the respective economies. Although we see some uptrend, countries need to increase their spending on R\&D to push the growth further. When it comes to driving growth, long-term policies serve the purpose rather than short-term.

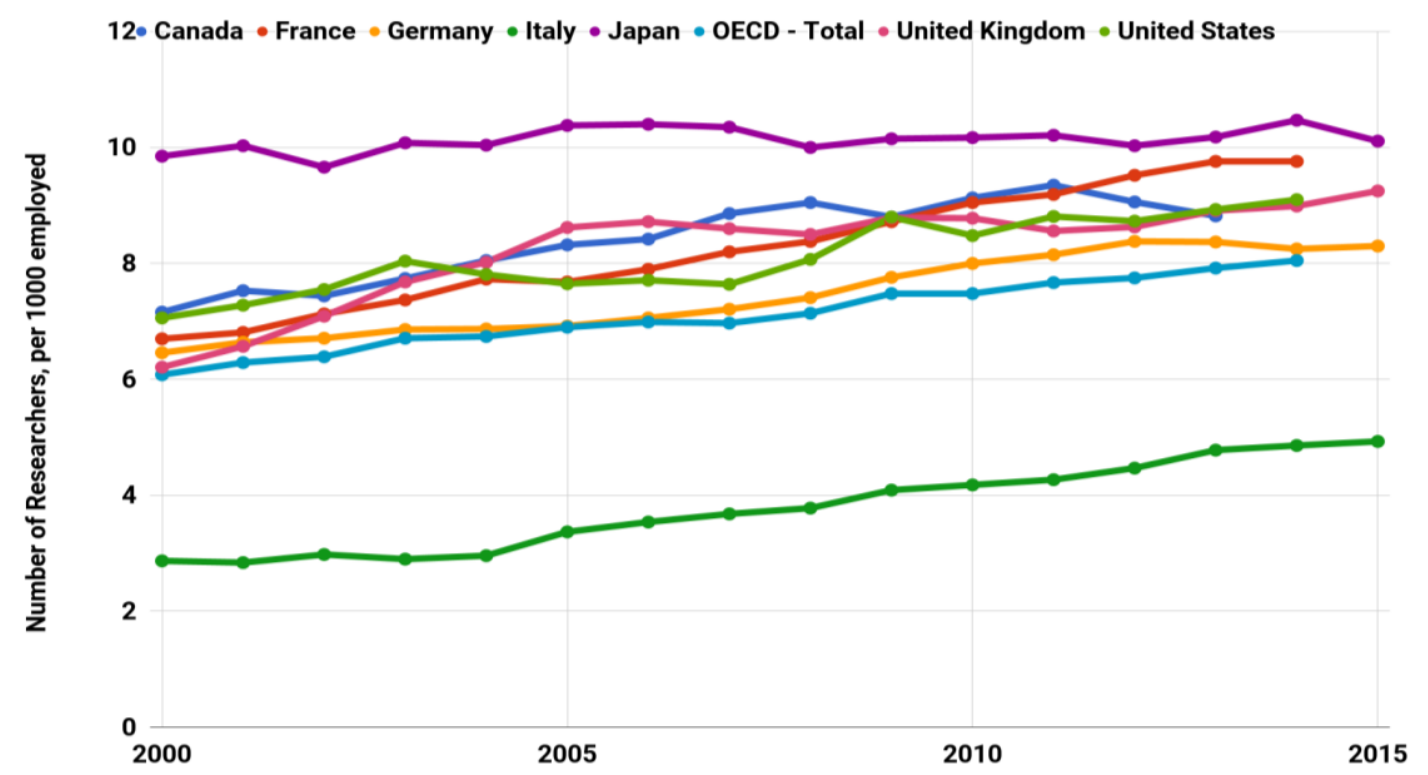

Figure 18. Number of Researchers, per 1000 employed 2000-2015 of G7 economies and OECD, Excluding China

Source: (OECD, 2017)

The traditional instruments to combat business cycles are no longer effective to achieve desired outcomes. Growth is no longer a component that can be increased in the short term, but a long-term endeavor. It has to be done with government grants, university grants, and the $R \& D$ budgets of companies whose balance sheets are constrained to quarterly results. Technology is immune to the short-term increase in spending and it involves solving a series of engineering problems before new products are introduced into the market. Since innovation fuels a greater share of the GDP component, influencing capital-intensive industries to invest will not sufficiently add to the economic output in the short term. Because innovation is a component that cannot be directly influenced by governments with traditional economic policies, Austrian school of thought becomes more applicable in understanding the economy. Laissez-faire economics will help the market to make optimal technological choices for growth. Rapid pace of technological change makes Austrian school of thought more relevant to our understanding of the complex modern economy and makes keynesian economics less influential.

\section{Conclusion}

We are entering a world where GDP growth will be heavily influenced by biotechnology, additive manufacturing, automation, robotics in consumer and industrial sectors, machine learning, and artificial intelligence. In this era, growth is an outcome of how quickly patents are turned into technological solutions to benefit human societies. Traditional Keynesian policies that call for short and medium term government influence is less impactful nowadays. Principles of the Austrian economics have greater relevance now that many parts of the economy cannot be influenced in the short and medium term. The age of technology requires laissez-faire economics to drive economic thinking where traditional tools of influence in short and medium term are obsolete to work in a modern, more diversified, and increasingly complex globalized economy.

\section{References}

Annual Consolidated Balance Sheet of the Eurosystem. (n.d.). Retrieved 21 June 2017, from https://www.ecb.europa.eu/pub/annual/balance/html/index.en.html

Blinder, A. S. (n.d.). Keynesian Economics. Retrieved 20 June 2017, from http://www.econlib.org/library/Enc/KeynesianEconomics.html

Cox, J. (2016, February 12). $\$ 12.3$ trillion of QE has added up to...this? CNBC. Retrieved from http://www.cnbc.com/2016/02/12/123-trillion-of-qe-has-added-up-tothis.html 
Federal Reserve Bank of St. Louis (2012) Percent of Employment in Manufacturing in the United States $\begin{array}{llllll}\text { (DISCONTINUED) (Graph). } & \text { (n.d.). Retrieved } 26 \quad \text { June 2017, from }\end{array}$ https://fred.stlouisfed.org/series/USAPEFANA

Federal Reserve Bank of St. Louis. (2017). All Federal Reserve Banks: Total Assets (Graph). (n.d.). Retrieved 26 June 2017, from https://fred.stlouisfed.org/series/WALCL

Federal Reserve Bank of St. Louis. (2017). San Francisco Tech Pulse (Graph). (n.d.). Retrieved 21 June 2017, from https://fred.stlouisfed.org/series/SFTPINDM114SFRBSF

GDP Growth (Annual \%). (n.d.). Retrieved 26 June 2017, from http://data.worldbank.org/indicator/NY.GDP.MKTP.KD.ZG

Jahan, S., Mahmud, A. S., \& Papageorgiou, C. (2014). What Is Keynesian Economics? Finance \& Development, 51(3), 53-54.

National Accounts Main Aggregates Database. (n.d.). Retrieved 24 June 2017, from https://unstats.un.org/unsd/snaama/dnlList.asp

OECD (2017). General Government Debt (Indicator). (n.d.). Retrieved 26 June 2017, from https://data.oecd.org/gga/general-government-debt.htm

OECD (2017). General Government Spending (Indicator). (n.d.). Retrieved 26 June 2017, from https://data.oecd.org/interest/long-term-interest-rates.htm

OECD (2017). Gross Domestic Spending on R\&D (Indicator). (n.d.). Retrieved 26 June 2017, from https://data.oecd.org/rd/gross-domestic-spending-on-r-d.htm\#indicator-chart

OECD (2017). Household Debt (Indicator). (n.d.). Retrieved 26 June 2017, from https://data.oecd.org/hha/household-debt.htm

OECD (2017). Long-term Interest Rates (Indicator). (n.d.). Retrieved 26 June 2017, from https://data.oecd.org/gga/general-government-spending.htm\#indicator-chart

OECD (2017). Researchers (Indicator). (n.d.). Retrieved 26 June 2017, from https://data.oecd.org/rd/researchers.htm\#indicator-chart

$\begin{array}{lllll}\text { Patents by } & \text { Technology. } & \text { (n.d.). Retrieved } 3 \text { May 2017, from }\end{array}$ http://stats.oecd.org/Index.aspx?DatasetCode=PATS_IPC

Perry, M. J. (2012, March 22). Manufacturing's Declining Share of GDP is a Global Phenomenon, and It's Something to Celebrate. Retrieved 19 June 2017, from https://www.uschamberfoundation.org/blog/post/manufacturing-s-declining-share-gdp-global-phenomenonand-it-s-something-celebrate/34261

Real Interest Rate (\%). (n.d.). Retrieved 26 June 2017, from http://data. worldbank.org/indicator/FR.INR.RINR?end=2016\&start=2016\&view=map

Rothbard, M. N. (1978). For a New Liberty: The Libertarian Manifesto (Revised Edition). New York: Collier Books.

World Bank Group. (n.d.). Retrieved 24 June 2017, from http://data.worldbank.org/indicator/NV.SRV.TETC.ZS

World Travel and Tourism Council. (2015). Travel and Tourism: Economic Impact 2015 Europe. London. Retrieved from https://www.wttc.org/-/media/files/reports/economic\%20impact\%20research/regional\%202015/europe2015

\section{Copyrights}

Copyright for this article is retained by the author(s), with first publication rights granted to the journal.

This is an open-access article distributed under the terms and conditions of the Creative Commons Attribution license (http://creativecommons.org/licenses/by/4.0/). 